Article

\title{
Environmental, Social, and Governance Disclosure, Ownership Structure and Cost of Capital: Evidence from the UAE
}

\author{
Nejla Ould Daoud Ellili \\ College of Business, Abu Dhabi University, P.O. Box 59911, Abu Dhabi, UAE; Nejla.Ellili@adu.ac.ae
}

Received: 1 August 2020; Accepted: 15 September 2020; Published: 18 September 2020

\begin{abstract}
The capital structure decision is one of the most vital financial decisions of the corporation that consists of determining the optimal combination of equity and debt for the companies that would reduce the cost of capital. The examination of the capital structure has always gained importance especially in the theoretical and empirical studies while there is no study of the relationship between the environmental, social, and governance (ESG), the ownership structure, and the cost of capital. In this context, this paper aims to examine the potential impacts of the ESG disclosure and ownership structure on the cost of capital by using a sample of 30 companies listed on the UAE financial markets (Abu Dhabi Stock Exchange and Dubai Financial Market) during the period 2010-2019. The data show that there is an increasing trend in the different non-financial corporate disclosures. The empirical results of various models show that the ESG disclosure, the insider and the institutional ownerships have negative and significant impacts on the cost of capital. Furthermore, the environmental and the governance disclosures reduce the cost of capital. This paper demonstrates the strong role played by the ESG disclosure and the ownership structure in reducing the cost of capital for the companies. These results would encourage the companies in implementing the best practices of the non-financial disclosures and regulating their corporate governance mechanisms.
\end{abstract}

Keywords: cost of capital; environmental; social and governance disclosure; ownership structure; UAE financial markets; panel data

\section{Introduction}

Over the last two decades, several researches have examined the extent of the non-financial disclosure about the environmental, social, and governance information as well as its potential impacts on the companies. Since the emergence of the Global Reporting Initiative (GRI) in 2001, the CSR disclosure has grown to be increasingly more common among the listed companies. The ESG analysis is becoming even more important in these challenging times of COVID-19 as it reflects how the companies should improve their non-financial reports. In this context of uncertainty, the quality and transparency of the information disclosed are vital keys that will boost the trust of the different stockholders and stakeholders. In the UAE, there is an increasing awareness about the importance of the ESG disclosure through establishing national structures to guide the companies in improving their transparency and adopting the best sustainability initiatives. In the sustainability efforts, the UAE has developed legislation for the environmental protection (Federal Law Number 24 of 1999), as well as created many bodies such as: Emirates Green Building Council (2006); Dubai Supreme Council of Energy (2009); Dubai Carbon Centre of Excellence (2011); Dubai Sustainability Council (2015). Their role is to promote further the sustainability initiatives and ensure the economic progress along with the sustainable development in the UAE. 
In the previous researches, there was a suggestion that the non-financial disclosure would have positive impacts on the companies such as the improvement of the corporate performance, reduction in the information asymmetry, enhancement of the company's reputation, as well as a decrease in the cost of capital [1-7].

The ownership structure has been also investigated by several studies and it has been considered as an effective corporate governance mechanism that contributes to the reduction of the management costs. In fact, the shareholders are interested in maximizing the value of the company while the managers are interested in maximizing their personal wealth that might be at the expense of the shareholders' interest. In the literature review, most of the studies have explored the impact of the ownership structure on the corporate performance [8-11]. However, only few studies have examined the relationship between the ownership structure and the cost of capital $[5,12,13]$.

In addition, the choice of the optimal capital structure and the minimization of the cost of capital are considered among the most important financial decisions of the company. Since the financial crisis of 2009, the capital structure has progressively gained more importance as many companies have faced a financial difficulties and bankruptcy. This topic has attracted the interest of many researchers and has been considered in many theoretical and empirical studies. In this actual year, this subject is even more important as the companies are facing serious financial problems due to the COVID-19 crisis and they should learn how to manage their cost of capital and change their financing decisions to maintain their financial performance.

Although there are similarities that this paper has with the previous researches regarding the examination of the extent of the non-financial disclosure in the annual reports or the association between the non-financial disclosure and the cost of equity or cost of debt, but this research goes further to examine the overall cost of capital including both cost of equity and cost of debt. In addition, this research does not only consider one type of non-financial disclosure but also a comprehensive non-financial disclosure including environmental, social, and governance information and the potential impact of the ownership structure by considering the different types of the shareholders (institutional, insider, blockholder, and foreign). This is a very interesting research opportunity because, in the UAE, the emphasis is placed on requiring all the listed companies to improve their compliance with the best practices of the ESG disclosure and manage efficiently their cost of capital.

Against this background, this study is conducted with the following main questions. First, to what extent do the UAE listed companies disclose ESG information? Second, is there any significant association between the ESG disclosure and the cost of capital? Third, is there any significant relationship between the ownership structure and the cost of capital?

This research contributes to the existing literature on the ESG disclosure in two important ways. First, this study focuses not only on one type of non-financial disclosure but on a more comprehensive disclosure including environmental, social, and governance information, whereas most previous researches have examined the environmental or/and corporate social responsibility disclosures [14-22]. Hence, the ESG disclosure of the listed companies needs to be furtherly explored as well, since this type of disclosure is done, so far, on a voluntary basis. Second, this study fills the gap in the financial literature concerning the possible relationships between the non-financial disclosure, the ownership structure, and the cost of capital. In addition, this research will shed light on the cost of capital management that needs to be enhanced and will recommend to the UAE regulatory authorities to develop a non-financial disclosure framework, and implement effective mechanisms to improve the compliance with the best ESG disclosure practices. The empirical findings will help the financial regulators in developing an ESG disclosure guideline to overcome the weaknesses of the cost of capital management and strengthen the corporate control within the UAE listed companies. To the knowledge of the author, there is no single research done in the UAE or abroad about the potential association between the ESG disclosure or/and the ownership structure and the cost of capital, so this research will shed light on his topic. 
The ESG data show a relative low level of the overall ESG score as well as low scores of the separated environmental, social, and governance disclosures. All the scores have an average value lower than 50. In addition, the ownership data indicate that the institutional investors hold the biggest part in the ownership structure of the different companies while the cost of capital data reveal that the companies have a cost of equity higher than the cost of debt. The effects of the ESG disclosure and ownership structure on the cost of capital have been examined by using panel data. The data show a positive trend in the ESG disclosure, which indicates that there is an increasing awareness about the importance of the non-financial disclosures by the listed companies on the UAE financial markets. The empirical results reveal a negative relationship between the overall ESG, the separated environmental, and governance disclosures and the cost of capital. In addition, the insider and the institutional ownerships have been found that they reduce the cost of capital, as well.

These results contribute in the financial literature by presenting a better knowledge about the level of the ESG disclosure of the listed companies in the UAE as well as a further understanding about the impact of the ESG disclosure and ownership structure on the cost of capital. This would help the listed companies to optimally determine their capital structures, enhance the quality of the funds, improve the quality of their non-financial reports, regulate their corporate governance mechanisms, and more efficiently manage their cost of capital.

The remainder of the paper is organized as follows: The second section contains a literature review about the ESG disclosure, ownership structure, and cost of capital. The third section focuses on variable, data, and empirical methodology. The empirical results and the conclusions are presented respectively in the fourth and fifth sections.

\section{Literature Review}

\subsection{Capital Structure Decisions}

The capital structure is a mixture of debt and equity held by a corporation. The determination of the capital structure was one of the most important researches in finance and they have been published after the theory of irrelevance in capital structure [23]. In fact, the MM theorem states that, under certain circumstances (no taxation, no transaction costs, no bankruptcy costs, efficient market), the company's value is independent of its financing decisions. In the objective to address the irrelevance hypothesis, the "no taxation" assumption has been relaxed as the debts are deductible from taxes and lead to an increase in the company's value [24] but also to an increase in the likelihood of bankruptcy. Therefore, the optimal capital structure reflects a debt level that balances between the benefits of debt financing and the bankruptcy costs. The capital structure has been examined by several theories: Agency theory (Section 2.1.1), Information Asymmetry theory (Section 2.1.2), Trade-off theory (Section 2.1.3), and Pecking Order theories (Section 2.1.4).

\subsubsection{Agency Theory}

The agency theory has been introduced in the corporate governance literature and its financial model focuses basically on the relationship between the shareholders (as principals) and the manager (as an agent). In particular, the managers may not always manage the company in the interests of the shareholders and, as a result, their goal would not be always the company's value maximization but the maximization of their human capital value, instead [8]. As a matter of fact, the managers may take an opportunistic approach and seek to get personal benefits from the agency relationship. Such a conflict of interest will create agency costs and require some corrective actions. According to the agency theory, managers can use the financial policy to obtain both monetary and non-monetary benefits (such as prestige, empire building) by undertaking non-profitable investments that would increase their human capital value. To restrict the manager's opportunistic actions, the amount of the debt should be increased to concentrate a large part of the capital structure under the control of the manager as a motivation to increase the company's value. The financial model resulting from 
this theory considers the debt as an instrument that allows the company to reduce the managerial discretion and moral hazard. In addition, the debts play an important role in reducing the free-cash flow within the companies as well as the investment in non-profitable projects and so it would be optimal for the companies to issue more debts to reduce the managerial discretion [25].

\subsubsection{Information Asymmetry Theory}

This theory states that the managers are always more informed than the investors about the actual and future financial situation of the company [26]. In this context, the managers can use the high level of debt as a good signal to be sent to the financial market to indicate the optimistic expectations about the future of the company as any failure in the payment of the principal or interest may lead to a financial distress. However, the issue of new equity would have a negative impact on the stock price as usually the managers schedule the issue of the new equity if the stock is overpriced. Due to the information asymmetry, the investors would always interpret the announcement of the new equity issue as a signal of overvaluation of the listed stock.

\subsubsection{Trade-Off Theory}

The trade-off theory suggests that companies are trying to maintain an optimal capital structure by considering the benefits and costs of debt [27]. The benefits of the debts include the tax shield, while the costs include the potential financial distress. In fact, the optimal capital structure is reached when the marginal benefit of the debt is equal to its marginal cost. The trade-off financial model states that companies try to converge over time their leverage towards a target level. It also predicts that the optimal leverage depends on the type of the industry as well as the level of tangible assets. More particularly, the industries with high tangible assets are expected to have higher leverage while the industries with low tangible assets are expected to have lower leverage.

\subsubsection{Pecking Order Theory}

The pecking order concept is totally based on the information asymmetry between the managers and investors as the managers are always more informed about the company's real value and its riskiness. This would affect the preference between internal and external financing $[26,28]$. To avoid the underinvestment evaluation, the managers would rather prefer to finance the new project by non-under evaluated financial securities such as internal funds or riskless funds. In fact, the pecking order financial model predicts that the companies do prefer the internal funds, and in the case that the external funds would be needed, the debt would be preferred over the equity and the companies would prefer to issue debts rather than equity to reduce the information costs and information asymmetry. The pecking order theory presumes that the managers of the companies with high growth opportunities and needs of funds do prefer to issue debts, as it is less subject to the information asymmetry and also due to the benefit of the tax shield.

The above-mentioned theories indicate that the determination of the capital structure depends on different motivations. As a result, the combination between equity and debt is explained by different relevant determinants such as the type of the industry. On the light of this, we formulate the following hypothesis.

Hypothesis 1 (H1). The capital structure varies across the industries for the companies listed on the UAE financial markets.

\subsection{Environmental, Social, and Governance Disclosure}

In the literature, most of the studies have examined the extent of the non-financial disclosure commonly in the annual reports of the companies (Section 2.2.1) while few other studies have explored the impact of the non-financial disclosure on the financial performance (Section 2.2.2). 


\subsubsection{Extent of the Non-Financial Disclosure}

In the literature, several studies have explored the extent of the non-financial disclosure in the annual reports of the companies in the developed countries while only few studies have emphasized on the GCC or MENA regions. These studies could be classified according to the type of the non-financial disclosure into: Environmental disclosure [14-16], social disclosure [17-22], and governance disclosure [29-31] while few others have considered the overall sustainability disclosure including different dimensions [32,33]. All these studies have used the content analysis of the annuals reports of the listed companies and constructed disclosure indices.

In the examination of the environmental disclosure, the contents of the annual reports of all the banks listed on the UAE financial markets have been explored during the period 2003-2013 by constructing a disclosure index and differentiating between the conventional and Islamic banks [15]. The empirical results show that the environmental disclosure of the UAE banks is at low level and the Islamic banks have lower disclosure index than the conventional banks. In a comparative analysis between the UAE and Jordan, there was an analysis of the environmental involvement and awareness as well as the environmental disclosure of the traded companies in four industries: Industry, commerce, insurance, and finance by using the data of 1998 [14]. The results show that, in both countries, there is a high level of environmental awareness and involvement but a low level of environmental disclosure. Most of the UAE and Jordanian companies disclose their environmental information in their annual reports while only few companies disclose standalone environmental reports. More recently and in a larger institutional context, the annual reports of 180 non-financial companies traded on nine financial market in the MENA region have been examined during 2010-2014. These countries include Saudi Arabia, UAE, Egypt, Qatar, Kuwait, Morocco, Oman, Tunisia, and Jordan [16]. The empirical results show that overall, the environmental disclosure is at a low level. More precisely, the average score varies across the countries and it is ranging between 6.18\% in Tunisia and $17.29 \%$ in Egypt while it is around $13 \%$ for all the other countries. In addition, the results indicate that there is positive trend and substantial increase in the cross-country environmental disclosure. In terms of industries, the industrial companies disclose more environmental information than the service companies.

In the examination of the social disclosure, there are several studies that have explored the annual reports of the companies across the GCC or/and MENA regions. In fact, there is a consensus on the increasing awareness over the time about the CSR disclosure among the companies in the different analyses of CSR reporting of companies operating in the UAE $[17,19,21,22,33,34]$. Similarly, there was a consideration of several CSR items disclosed in the annual reports of Qatari companies [35]. These items include human resources, product development, and community involvement. The results showed that most companies disclosed information related to CSR as a narrative disclosure in the chairman's report. In a larger institutional context, the CSR content in the annual reports of the companies traded on the GCC financial markets have been explored and it was found that, on average, the level of the disclosure is low $[18,20]$.

In the examination of the governance disclosure, the extent of the corporate governance information has been explored on the websites of 77 listed companies in the Saudi financial market in 2005 and 2006. It was found that most of the companies disclose their corporate governance information on their websites in compliance with the guidance published by Saudi Arabian Capital Market Authority in 2006 [29]. In addition, the results show that the banks have the highest disclosure level while the industry and services sectors have the lowest disclosure level. Similarly, the extent of the corporate governance information in the annual reports of the listed companies on UAE financial markets has been examined. By constructing a disclosure index that includes items about ownership structure, investors' rights, management structure and processes, external audit and non-audit services, and transparency disclosures, the results indicate that the banks have a high corporate governance disclosure level [30,31].

In the consideration of the overall sustainability disclosure, the content of the annual reports of the Egyptian listed companies in 2002 has been explored by constructing an index consisting of 
34 disclosure items including environmental, energy, human resources, customer, and community factors [32]. The empirical results show that overall, the sustainability disclosure is relatively low and varies significantly across corporations. More recently, the extent of the economic, environmental, and social disclosure has been examined in the annual reports of the listed banks on UAE. The empirical findings reveal that the overall sustainability disclosure for all the banks has a low level. In addition, the economic disclosure has the highest level while the environmental disclosure has the lowest [33].

All the above-mentioned researches agree that the non-financial disclosure, regardless of its type, is still at a low level but it is improving over time. In the UAE, from 2009, all the listed companies are required to disclose their standalone corporate governance reports including information about the board of directors and the different committees. In addition, there is an increasing awareness about the importance of the ESG disclosure within the UAE as well as many initiatives to motivate the listed companies to disclose their non-financial reports and improve their transparency.

Following the above arguments, we develop the below hypothesis:

Hypothesis 2 (H2). There is a positive trend in the ESG disclosure for the UAE listed companies.

Hypothesis 2a (H2a). There is a positive trend in the environmental disclosure for the UAE listed companies.

Hypothesis $\mathbf{2 b} \mathbf{( H 2 b )}$. There is a positive trend in the social disclosure for the UAE listed companies.

Hypothesis 2c (H2c). There is a positive trend in the governance disclosure for the UAE listed companies.

\subsubsection{Impact of the Non-Financial Disclosure on the Cost of Capital}

In the literature, most of the previous researches have investigated the impact of the non-financial disclosure on the financial performance [36-39]. In addition, the non-financial disclosure has several other positive impacts different levels such as: Improving the accuracy of the analyst forecast [40]; reducing the information asymmetry [41]; minimizing the agency costs [42]; and enhancing the company's reputation [43].

There are few studies that have explored the effect of the non-financial disclosure on the cost of capital [1-7]. In fact, several studies confirm that there is a negative relationship between the CSR disclosure and the cost of capital for the U.S. companies. This result is explained by the fact that the CSR disclosure reduces the information asymmetry and increases the transparency, which leads to a reduction in the cost of capital [2,3]. More recently, the analysis of the association between the CSR disclosure and the cost of equity has been extended by considering the international context, the country-level stakeholder orientation, and corporate governance models [4]. By studying companies from 31 countries, the empirical findings corroborate the results of the previous studies and reveal a negative association between the CSR disclosure and the cost of capital. This negative relationship is more pronounced in the countries with high stakeholder orientation. In addition, this result is even stronger in the countries or companies with high level of financial opacity. Knowing that the financial opaqueness increases the information asymmetry as well as the cost of capital and the CSR disclosure plays as a substitute of the financial disclosure. In the above studies, the cost of capital is measured only by the cost of equity while the study [5] considers the cost of equity, the cost of debt, as well as the weighted average cost of capital and includes companies traded on Tokyo Stock Exchange during the period 2007-2013. The empirical results reveal insufficient evidence about the negative impact of the CSR disclosure on the cost of capital. This finding is explained by the economic stagnancy of the Japanese companies, the low awareness about the non-financial disclosure, the non-diversification of the debt market in Japan compared to the USA and UK markets, and also the importance of the relationship with the banks in accessing to the external funds as well as the risk for facing financial restrictions for small and emerging companies. In a different institutional context, the relationship between the CSR disclosure and the cost of capital has been explored by considering the effect of the information asymmetry for the German companies [6]. Their empirical results indicate that the 
CSR disclosure not only reduces the cost of equity but also the information asymmetry. This result is explained by the fact that the higher CSR disclosure is associated with better risk management in the companies leading to a lower cost of capital and less information asymmetry. This result suggests that the CSR disclosure is more important than a non-financial disclosure in satisfying the different stakeholders and could be considered as an operating license that generates significant reduction in the companies' cost of capital. The examination of the relationship between the CSR disclosure and the cost of debt by using European non-financial companies and data during 2005-2012 [7] reveals that the higher CSR disclosure is not only associated with a lower interest rate, but also with a better debt rating of the company.

The above-mentioned studies consider only the CSR reports in the analysis of the relationship between the non-financial disclosure and the cost of capital while there is another study that has considered the environmental risk management [1]. By using a sample of 267 US companies during 1999-2002, the empirical results show that the higher environmental risk management is associated with a lower cost of capital leading to an increase in the economic performance.

All the previous researches have considered either the CSR, environmental, or sustainability disclosure while this research uses a comprehensive disclosure including the environmental, social, and governance information. Following the above arguments, the following hypothesis is:

Hypothesis 3 (H3). There is a negative association between the ESG disclosure and the cost of capital.

Hypothesis 3a (H3a). There is a negative association between the environmental disclosure and the cost of capital.

Hypothesis $\mathbf{3 b} \mathbf{b} \mathbf{H} \mathbf{3 b})$. There is a negative association between the social disclosure and the cost of capital.

Hypothesis 3c $\mathbf{( H 3 c )}$. There is a negative association between the governance disclosure and the cost of capital.

\subsection{Ownership Structure}

The ownership structure is defined as the distribution of common equity and capital among the different holders' identities. It is of a great importance in the corporate governance as it determines the corporate efficiency and the different investment decisions including, among others, the determination of the capital structure associated with the cost of capital. The examination of the relationship between the ownership structure and the cost of capital needs the differentiation between the different types of shareholders: Institutional ownership (Section 2.3.1), insider ownership (Section 2.3.2), blockholder ownership (Section 2.3.3), and foreign ownership (Section 2.3.4).

\subsubsection{Institutional Ownership}

In the corporate governance literature, several studies have examined the impact of the institutional ownership on the corporate performance by considering three hypotheses of efficient monitoring, conflict of interests, and strategic alignment [44]. According to the first hypothesis, the institutional investors are more efficient in monitoring the managers and thus a positive impact on the financial performance. Meanwhile, the second and the third hypotheses predict a negative association between the institutional ownership and the financial performance and this is due to the fact that the institutional investors may have strategic interests aligned on those of the managers and this would affect the quality of the institutional efficient monitoring.

Similarly, in the exploration of the relationship between the institutional ownership and the cost of capital, we consider the abovementioned conflicting opinions. On one side, and based on the efficient monitoring hypothesis, the institutional investors have more expertise and experience in monitoring the managers, more efficiently managing the companies, and taking the most appropriate financial decisions and hence a negative impact on the cost of capital. Within this opinion, it was found that the 
institutional ownership decreases the cost of equity and enhances the corporate social performance of the companies in Japan by mitigating the information asymmetry [5]. However, the institutional investors may have strategic interests aligned on those of the managers and this would make them less motivated in interfering in the capital structure decisions and less concerned about the cost of capital. Following the above contradictory arguments, the third hypothesis is:

Hypothesis 4 (H4). There is a negative association between the institutional ownership and the cost of capital.

\subsubsection{Insider Ownership}

The insider ownership was the subject of several previous researches that examined the impact of the ownership structure on the corporate performance. In fact, there are two contradicting views. On one side, the agency theory suggests that the high managerial ownership leads to the alignment of the managers' interests with those of the shareholders and hence the convergence of interests hypothesis that states that the managerial ownership has a positive impact on the financial performance [8]. The non-linear relationship between the managerial ownership and the financial performance was confirmed and this result suggests the coexistence of the convergence of interests hypothesis along with the managerial entrenchment that states that the managerial ownership has a negative impact on the corporate performance [9]. In addition to the conflicts of interests between the managers and the shareholders, another conflict of interests was introduced, which is the conflict between the shareholders and the creditors. In fact, the shareholders may expropriate the creditors' wealth by investing in projects and making financial decisions that would reduce the value of the company's debt [8]. In this context, the impact of the managerial ownership has been examined for the Japanese companies during 1997-2004 [13] and the empirical results show a positive association between the two variables. In addition, this result suggests that the owner-managers may invest in risky projects and transfer the risk to the creditors and this risk shifting behavior may lead the creditors to require a higher cost of debt for the companies with high managerial ownership. However, there is a confirmation of a nonmonotonic relationship between the managerial ownership and the cost of the debt [45]. More particularly, at low levels of managerial ownership, there is a positive association between the managerial ownership and the cost of debt as evidence of the risk shifting. Meanwhile, at high levels, there is a negative relationship association between the managerial ownership and the cost of debt.

Hypothesis 5 (H5). There is a positive association between the insider ownership and the cost of capital.

\subsubsection{Blockholder Ownership}

The blockholders are defined as the major shareholders who own at least $5 \%$ of the capital of the companies. In the financial literature, there is a consensus on the positive impact of the blockholders on the corporate performance. In fact, the blockholders are known for their power and strong incentives in controlling efficiently the managers $[10,46]$. Usually, the concentrated ownership structures are associated with low governance problems. However, the blockholders may have private benefits of control and aligned interests with those of the managers at the expense of the minor shareholders and this may lead to the wealth expropriation within the company $[9,10]$. In the context of the UAE, it was found that the presence of the blockholders in the ownership structure of the company does not necessarily guarantee a good performance, which suggests that the blockholders are not always efficient monitors as by the managerial entrenchment [47].

In the examination of the relationship between the blockholders and the cost of bank debt, the data of companies from 22 East Asian and Western European countries have been examined during the period 1996-2008 [12]. In this analysis, it has been suggested that the excess in the control rights of the blockholders has facilitated the tunneling and moral hazard activities within the companies and this may increase the monitoring costs and the credit risk of the banks as well as the cost of the debt. 
Hypothesis 6 (H6). There is a positive association between the blockholder ownership and the cost of capital.

\subsubsection{Foreign Ownership}

In the corporate governance, the foreign investors are considered as efficient and active monitors of the corporate investment and financial decisions. More particularly, the foreign ownership is considered, among others, as an important determinant of the corporate performance and several studies have empirically examined the relationship between the two variables. In fact, the presence of the foreign investors in the ownership structure leads to the financial performance maximization as well as the shareholders' wealth [48]. In addition, the presence of the foreign investors is positively associated with the audit quality, ensuring the minimization of the information asymmetry [49]. Usually, the foreign investors hold large capital in the company, and they are more concerned about the improvement of the corporate performance.

Similarly, in the exploration of the relationship between the foreign ownership and the cost of capital, we consider the above results confirming that the foreign investors have always a positive impact on the financial performance and monitor more actively the financial decisions as well as the management of the company. Hence, we suggest a negative impact on the cost of capital. In this analysis, we predict that the foreign investors control effectively the cost of capital of the firm and then the following hypothesis:

Hypothesis 7 (H7). There is a negative association between the foreign ownership and the cost of capital.

\section{Data and Methodology}

\subsection{Data}

The objective of this paper is to determine the potential impacts of the ESG disclosure and ownership structure on the cost of capital of the companies listed on ADX and DFM using data during the period 2010-2019. The data have been collected from Bloomberg Terminal and the choice of the companies is based on the availability of the ESG data. The number of companies included in this analysis is 30 and the companies are operating in several industries as shown on the Table 1.

Table 1. Companies and industries.

\begin{tabular}{cc}
\hline Industry & Number of Companies \\
\hline 1- Banks & 10 \\
2- Consumer Staples & 2 \\
3- Energy & 3 \\
$4-\quad$ Industrial & 1 \\
$5-\quad$ Investment and Financial Services & 3 \\
6- Real Estate & 6 \\
7- Telecommunication & 3 \\
8- Transportation & 2 \\
Total & 30 \\
\hline
\end{tabular}

\subsection{The Choice of Variables:}

The data used in this analysis are divided into four groups: ESG disclosure variables (Section 3.2.1), ownership structure variables (Section 3.2.2), cost of capital variables (Section 3.2.3), and control variables (Section 3.2.4)

\subsubsection{ESG Score Variables}

In this analysis, there are four ESG variables: The overall ESG score as well as the separated Environmental, Social, and Governance scores. The scores are available on Bloomberg Terminal, and they range between 0 and 100. Bloomberg assesses the listed companies on an annual basis and 
collects ESG information disclosed by the companies in their annual reports, websites, corporate governance reports, as well as sustainability or corporate social responsibility reports. All the score definitions are presented in the Table 2.

Table 2. Environmental, social, and governance (ESG) score variables.

\begin{tabular}{ccc}
\hline Variables & Notation & Data Coverage \\
\hline ESG Score & ESG & Environmental, social and governance information \\
\hline Environmental Score & ES & $\begin{array}{r}\text { Carbon emission, climate change effect, pollution, renewable } \\
\text { energy, water use, energy consumption }\end{array}$ \\
\hline Social Score & SS & $\begin{array}{c}\text { Community relations, human rights, employee's turnover, women } \\
\text { in management }\end{array}$ \\
\hline Governance Score & GS & $\begin{array}{c}\text { Board size, board duality, independent directors, women in board, } \\
\text { number of meetings, percentage of attendance in the meetings }\end{array}$ \\
\hline
\end{tabular}

\subsubsection{Ownership Structure Variables}

In this analysis, there are four ownership variables: The institutional ownership, the insider ownership, the blockholder ownership, and the foreign ownership. The annual values of the ownership percentages are available on Bloomberg Terminal. All the ownership variables definitions are presented in the Table 3.

Table 3. Ownership structure variables.

\begin{tabular}{|c|c|c|}
\hline Variables & Notation & Measure \\
\hline $\begin{array}{l}\text { Institutional } \\
\text { Ownership }\end{array}$ & INS & The part of capital owned by the institutional shareholders \\
\hline Insider Ownership & $\mathrm{IO}$ & The part of capital owned by the corporate insiders \\
\hline $\begin{array}{l}\text { Block holder } \\
\text { Ownership }\end{array}$ & $\mathrm{BO}$ & $\begin{array}{l}\text { The part of capital owned by the external shareholders having more } \\
\text { than } 5 \%\end{array}$ \\
\hline Foreign Ownership & FO & The part of capital owned by the foreign shareholders \\
\hline
\end{tabular}

\subsubsection{Cost of Capital Variables}

In this analysis, the cost of capital is the dependent variable and it is measured by the weighted average cost of capital (WACC). To further examine the cost of capital, Table 4 shows the decomposition of the WACC into cost of equity, cost of debt, and cost of preferred equity to gain further information about the magnitude of the company's capital structure components.

Table 4. Cost of capital variables.

\begin{tabular}{|c|c|c|}
\hline Variables & Notation & Measure \\
\hline Cost of Equity & $\mathrm{CE}$ & Risk Free Rate + Beta (Expected Market Return-Risk Free Rate) \\
\hline Cost of Debt & $\mathrm{CD}$ & $\begin{array}{c}{[(\text { Note Rate } \times \text { Short Debt/Total Debt })+(\text { Bond Rate } \times \text { Long Term }} \\
\text { Debt/Total Debt })] \times(1 \text {-Effective Tax Rate })\end{array}$ \\
\hline $\begin{array}{l}\text { Cost of Preferred } \\
\text { Equity }\end{array}$ & $\mathrm{CPE}$ & Preferred Dividend/Preferred Equity \\
\hline $\begin{array}{l}\text { Weighted Average Cost } \\
\text { of Capital }\end{array}$ & WACC & $\begin{array}{c}\mathrm{CE} \times(\text { Equity } / \text { Equity }+ \text { Debt })+\mathrm{CD} \times(\text { Debt } / \text { Equity }+ \text { Debt })+C P E \\
\times(\text { Preferred Equity/Equity }+ \text { Debt })\end{array}$ \\
\hline
\end{tabular}

\subsubsection{Control Variables}

The independent variables include the ESG score, the ownership structure variables, as well as firm-level control variables, such as debt ratio, firm's size, and corporate performance measured by the 
return on asset (ROA). Table 5 shows all the detailed measures of the control variables included in this analysis.

Table 5. Control variables.

\begin{tabular}{ccc}
\hline Variables & Notation & Measure \\
\hline Debt Ratio & DR & Total Liabilities/Total Assets \\
Firm's Size & SIZE & Log (Total Assets) \\
Return on Assets & ROA & Return on Assets = Net Income/Average of Total Assets \\
\hline
\end{tabular}

\subsection{Methodology}

The multivariate regressions analysis of panel data is employed in this study to examine the impact of the different ESG scores and ownership structure on the company's cost of capital. These panel data regressions help in exploring the cross sectional and the time series data simultaneously. The general form of the model is as following:

$$
\begin{gathered}
\text { WACC }_{\text {it }}=\beta_{0}+\beta_{1} \mathrm{ESG}_{\text {it }}+\beta_{2} \mathrm{INS}_{\text {it }}+\beta_{3} \mathrm{IO}_{\text {it }}+\beta_{4} \mathrm{BO}_{\text {it }}+\beta_{5} \mathrm{FO}_{\text {it }}+\beta_{6} \mathrm{AGE}_{i t}+\beta_{7} \\
\text { SIZE }_{\text {it }}+\beta_{8} \mathrm{ROA}_{\text {it }}+\varepsilon_{\mathrm{t}}
\end{gathered}
$$

\section{Empirical Results}

\subsection{Descriptive Statistics}

Table 6 provides a summary of the overall ESG score as well the separated environmental, social, and governance scores by industry. Overall, the industry that has the highest ESG score is the Transportation while the Real Estate has the lowest ESG score. In this sample, the Transportation industry includes airlines companies that are operating at international level while most of the activities of the Real Estate companies are limited within the UAE. The pressure of the international stakeholders could be considered as a strong pressure on the companies to improve their ESG scores.

Table 6. ESG disclosure per industry.

\begin{tabular}{ccccc}
\hline Industry & ESG & ES & SS & GS \\
\hline 1- Banks & 23.73 & 27.93 & 32.24 & 37.39 \\
2- Consumer Staples & 14.75 & 7.75 & 17.54 & 45.89 \\
3- Energy & 14.89 & 11.43 & 15.28 & 38.94 \\
4- Industrial & 24.89 & 17.74 & 21.05 & 45.23 \\
5- Investment and Financial Services & 10.04 & 4.71 & 4.28 & 35.56 \\
6- Real Estate & 9.57 & 8.10 & 12.17 & 29.07 \\
7- Telecommunication & 18.64 & 22.62 & 28.71 & 35.85 \\
8- Transportation & 27.09 & 27.97 & 54.73 & 47.08 \\
\hline
\end{tabular}

In addition, and on average, for most of the industries, the GS is the highest score (except the Transportation) while the ES is the lowest score (except the Investment and Financial Services). This result could be explained by the fact that from 2009, all the listed companies are required to disclose their corporate governance reports while the environmental disclosure is still done at a voluntary basis.

Table 7 provides a summary of the ownership variables by industry. Overall, the institutional investors hold the highest part of the company's ownership except for the Industrial and Transportation industries where the foreigner investors hold the highest ownership part. This could be due to the fact to the international business activities of these two industries. The banks and the Telecommunication companies have the highest institutional ownerships. The insiders hold only small ownership parts in the Banks, Industrial, Investment and Financial Services, and Real Estate industries while the blockholders invest only in Banks, Industrial, and Real Estate. 
Table 7. Ownership structure per industry.

\begin{tabular}{ccccc}
\hline Industry & INS & IO & BO & FO \\
\hline 1- Banks & 49.40 & 2.63 & 1.19 & 20.37 \\
2- Consumer Staples & 23.24 & 0.00 & 0.00 & 18.09 \\
3- Energy & 35.27 & 0.00 & 0.00 & 21.15 \\
4- Industrial & 24.34 & 2.64 & 8.34 & 68.83 \\
5- Investment and Financial Services & 34.00 & 2.69 & 0.00 & 27.94 \\
6- Real Estate & 22.51 & 2.63 & 3.49 & 22.31 \\
7- Telecommunication & 52.12 & 0.00 & 0.00 & 3.89 \\
8- Transportation & 27.10 & 0.00 & 0.00 & 68.93 \\
\hline
\end{tabular}

Table 8 provides a summary of the WACC as well as the costs of equity, debt, and preferred stocks. None of the companies included in the sample has issued preferred stocks. On average, the equity is the most expensive capital for all the companies across all the industries. This finding confirms the pecking order theory predictions stating that the equity is less preferable than the debt due to its high cost related to the uncertainty about the future dividend distribution [28]. The Investment and Financial Services industry has the highest WACC as well as the highest costs of equity and debt due to the uncertainty of the investment on the financial markets while the Industrial industry has the lowest WACC and the lowest cost of equity. This result could be explained by the fact that in the Industrial and Consumer staples industries, there are more tangible assets than in the Investment and Services industry. In addition, the assets' tangibility is highly associated with the high liquidation value. This result is consistent with the trade-off theory suggestions stating that the capital composition is different from one industry to another [27]. In fact, the tangible assets are considered as collateral in case of bankruptcy and the costs associated with the capital would be reduced. In addition, Table 8 shows that the banks have the highest weight of debt in their capital structures as this industry is the largest and under a high public pressure. As per the information asymmetry theory, the debts are used by the banks as positive signals and optimistic expectations sent to the financial markets [26].

Table 8. Cost of capital per industry (\%).

\begin{tabular}{|c|c|c|c|c|c|c|}
\hline \multirow{2}{*}{ Industry } & \multirow{2}{*}{ WACC } & \multicolumn{2}{|c|}{ Equity } & \multicolumn{2}{|c|}{ Debt } & \multirow{2}{*}{ CPE } \\
\hline & & CE $(\%)$ & Weight $(\%)$ & $\mathrm{CD}(\%)$ & Weight (\%) & \\
\hline 1- Banks & 6.95 & 12.71 & 45.56 & 2.13 & 54.44 & 0 \\
\hline 2- Consumer Staples & 10.79 & 12.69 & 82.50 & 1.83 & 17.50 & 0 \\
\hline 3- Energy & 7.22 & 13.1 & 46.15 & 2.18 & 53.85 & 0 \\
\hline 4- Industrial & 5.7 & 9.76 & 47.20 & 2.07 & 52.80 & 0 \\
\hline 5- Investment and Financial Services & 12.99 & 16.74 & 72.79 & 2.96 & 27.21 & 0 \\
\hline 6- Real Estate & 12.41 & 17.5 & 66.09 & 2.49 & 33.91 & 0 \\
\hline 7- Telecommunication & 8.37 & 11.77 & 63.08 & 2.56 & 36.92 & 0 \\
\hline 8- Transportation & 9.86 & 11.36 & 82.92 & 2.58 & 17.08 & 0 \\
\hline
\end{tabular}

Table 9 shows the descriptive statistics of the disclosure, cost of capital, and ownership structure variables. As shown above per industry, the average of the governance disclosure score (37.32) is the highest as the corporate governance reports are required for all the listed companies on the UAE financial markets. For the cost of capital variables, the cost of equity is always the highest with an average of $13.89 \%$. Regarding the ownership structure variables, the UAE listed companies have the highest part of their capital held by the institutional investors with an average of $37.78 \%$. 
Table 9. Descriptive statistics for all variables.

\begin{tabular}{ccccc}
\hline Variables & Mean & Standard Deviation & Minimum & Maximum \\
\hline ESG & 18.60 & 14.03 & 2.07 & 50.44 \\
ES & 20.38 & 14.99894 & 1.79 & 47.33 \\
SS & 24.97 & 17.98 & 3.33 & 57.98 \\
GS & 37.32 & 13.09 & 8.93 & 64.29 \\
WACC & 9.25 & 5.82 & 3.2 & 51.5 \\
CE & 13.89 & 6.81 & 5.3 & 51.5 \\
CD & 2.35 & 1.01 & 0 & 5.3 \\
CPE & 0.02 & 0.36 & 0 & 6.0 \\
INS & 37.78 & 27.21 & 0 & 99.98 \\
IO & 1.82 & 8.35 & 0 & 72.22 \\
BO & 1.39 & 8.72 & 0 & 96.85 \\
FO & 24.86 & 30.64 & 0 & 100 \\
\hline
\end{tabular}

Table 10 shows the trend in the ESG score as well as in the separated environmental, social, and governance scores. The average of all the ESG scores of the UAE listed companies have increased from 2010 to 2019. More particularly, the environmental score has increased from 10.41 in 2009 to 24.13 in 2019, the social score from 22.19 to 27.09 , the governance score from 31.63 to 41.23 , and overall ESG score from 14.62 to 26.86 .

Table 10. Trend in ESG scores during 2010-2019.

\begin{tabular}{ccccccccccc}
\hline & $\mathbf{2 0 1 0}$ & $\mathbf{2 0 1 1}$ & $\mathbf{2 0 1 2}$ & $\mathbf{2 0 1 3}$ & $\mathbf{2 0 1 4}$ & $\mathbf{2 0 1 5}$ & $\mathbf{2 0 1 6}$ & $\mathbf{2 0 1 7}$ & $\mathbf{2 0 1 8}$ & $\mathbf{2 0 1 9}$ \\
\hline ESG & 14.62 & 15.41 & 18.51 & 17.75 & 16.72 & 18.32 & 19.11 & 21.82 & 19.53 & 26.86 \\
ES & 10.41 & 16.92 & 27.08 & 24.40 & 23.20 & 21.61 & 18.38 & 22.71 & 16.06 & 24.13 \\
SS & 22.19 & 24.98 & 29.00 & 25.88 & 28.00 & 23.81 & 25.00 & 24.89 & 21.56 & 27.09 \\
GS & 31.63 & 31.97 & 37.42 & 35.64 & 34.96 & 37.12 & 39.68 & 39.99 & 41.45 & 41.23 \\
\hline
\end{tabular}

Table 11 shows the correlations between the three groups of variables: Ownership structure, disclosure, and cost of capital. As shown below, the institutional ownership, insider ownerships, and the ESG disclosure are negatively and significantly correlated to the cost of capital (WACC) while only the institutional ownership is positively and significantly correlated to the ESG and social disclosures. The foreign investors are positively and significantly related to the governance disclosure. The foreign investors and the governance disclosure are negatively and significatively correlated to the cost of equity.

Table 11. Correlation matrix.

\begin{tabular}{|c|c|c|c|c|c|c|c|c|c|c|c|}
\hline & INS & IO & BO & FO & ESG & ES & SS & GS & WACC & $\mathrm{CE}$ & CD \\
\hline INS & 1.000 & & & & & & & & & & \\
\hline $\mathrm{IO}$ & -0.169 * & 1.000 & & & & & & & & & \\
\hline $\mathrm{BO}$ & -0.156 * & 0.699 * & 1.00 & & & & & & & & \\
\hline $\mathrm{FO}$ & -0.493 * & 0.129 * & 0.048 & 1.000 & & & & & & & \\
\hline ESG & $0.246^{*}$ & -0.074 & -0.008 & 0.060 & 1.000 & & & & & & \\
\hline ES & 0.061 & -0.107 & -0.169 & 0.079 & 0.949 * & 1.000 & & & & & \\
\hline SS & $0.199 *$ & -0.086 & -0.031 & 0.090 & 0.790 * & $0.648 *$ & 1.000 & & & & \\
\hline GS & 0.0955 & -0.029 & 0.018 & $0.152 *$ & -0.665 * & 0.380 * & $0.419 *$ & 1.000 & & & \\
\hline WACC & -0.119 * & $-0.125 *$ & -0.061 & -0.043 & -0.145 * & -0.178 & -0.119 & -0.078 & 1.000 & & \\
\hline $\mathrm{CE}$ & -0.098 & -0.150 * & -0.098 & -0.179 * & -0.109 & -0.084 & -0.074 & -0.193 * & $0.801 *$ & 1.000 & \\
\hline $\mathrm{CD}$ & 0.055 & 0.023 & 0.066 & -0.032 & -0.021 & -0.122 & 0.044 & -0.021 & -0.040 & $-0.227 *$ & 1.000 \\
\hline
\end{tabular}

* Significant at a level of $5 \%$. 


\subsection{Analysis of Results}

\subsubsection{Impact of the Non-Financial Disclosure on the Cost of Capital}

The estimation of the panel data with fixed effects rejects the presence of the individual effects. In consequence, we consider the coefficients of the pooled OLS estimation since the data consist of $\mathrm{N}^{*} \mathrm{~T}$ observations. The tests of variance inflation factor (VIF) rejects the multicollinearity problem, and the respective tests of Durbin-Watson and Breusch-Godfrey reject the autocorrelation problem. However, the test of Breush-Pagen detects the heteroscedasticity problem. This problem was solved by using the logarithmic transformation of the dependent variable.

Table 12 shows the empirical results of the impact of the corporate non-financial disclosures on the overall cost of capital. Regarding the objective of further investigating the separate impacts of the different non-financial disclosures on the cost of capital, model (1) is estimated for the overall ESG disclosure, while model (2) is estimated for all the different corporate disclosure and then re-estimated in models (3), (4), and (5) for the separated corporate disclosures. The results show that the overall ESG is negatively and significantly associated with the cost of capital. The findings of the baseline model (2) indicate that both environmental and governance disclosures have negative and significant impact on the cost of capital, which has been corroborated in the models (3), (4), and (5). With regards to the control variables, the leverage has always a positive and significant impact on the cost of capital while the ROA is always associated negatively and significantly to the cost of capital. Furthermore, the same regression has been re-estimated to further examine the separate impacts of the non-financial disclosures on the cost of equity and cost of debt, respectively. The empirical findings show that both environmental and governance disclosures have negative and significant impacts on the cost of equity (see Table A1 in Appendix A) while all the non-financial disclosure including environmental, social, and governance have a negative and significant relationship with the cost of debt (see Table A2). In all the regressions, the leverage is always positively and significantly associated with both types of costs while the impact of the ROA is always negative and significant. According to the above-mentioned results, the environmental and the governance disclosures along with low level of leverage and high level of ROA are considered on the financial markets as positive information about the financial health of the company that would encourage the stockholders and creditors to reduce their required returns.

Table 12. Impact of the non-financial disclosure on weighted average cost of capital (WACC).

\begin{tabular}{|c|c|c|c|c|c|}
\hline \multirow{2}{*}{ Variables } & \multicolumn{4}{|c|}{ Cost of Capital } & \multirow[b]{2}{*}{ (5) } \\
\hline & (1) & (2) & (3) & (4) & \\
\hline ESG & $\begin{array}{c}-0.0124^{* * *} \\
(-2.81)\end{array}$ & & & & \\
\hline ES & & $\begin{array}{c}-0.0232 * \\
(-1.88)\end{array}$ & $\begin{array}{c}-0.0150 * \\
(-1.75)\end{array}$ & & \\
\hline SS & & $\begin{array}{c}-0.0024 \\
(-1.29)\end{array}$ & & $\begin{array}{c}-0.0076 \\
(-1.37)\end{array}$ & \\
\hline GS & & $\begin{array}{c}-0.0372 \text { *** } \\
(-2.94)\end{array}$ & & & $\begin{array}{c}-0.0186^{* * *} \\
(-2.72)\end{array}$ \\
\hline SIZE & $\begin{array}{c}-0.5197 \\
(-1.63)\end{array}$ & $\begin{array}{c}-2.5841 \text { * } \\
(-1.69)\end{array}$ & $\begin{array}{c}-2.1863 \\
(-1.55)\end{array}$ & $\begin{array}{c}-1.2762 \\
(-1.55)\end{array}$ & $\begin{array}{l}-0.7677 \\
(-0.90)\end{array}$ \\
\hline LEVERAGE & $\begin{array}{c}10.8090^{* * *} \\
(4.95)\end{array}$ & $\begin{array}{c}6.3304^{*} \\
(1.71)\end{array}$ & $\begin{array}{c}6.9588^{*} \\
(1.89)\end{array}$ & $\begin{array}{c}7.1773^{* * *} \\
(4.10)\end{array}$ & $\begin{array}{c}10.7775^{* * *} \\
(4.92)\end{array}$ \\
\hline ROA & $\begin{array}{c}-0.0302 \text { ** } \\
(-2.18)\end{array}$ & $\begin{array}{c}-0.1655 \text { *** } \\
(-3.25)\end{array}$ & $\begin{array}{c}-0.1528^{* * *} \\
(-3.17)\end{array}$ & $\begin{array}{c}-0.0270 * \\
(-1.73)\end{array}$ & $\begin{array}{l}-0.0444 \\
(-1.01)\end{array}$ \\
\hline $\mathrm{R}_{\text {overall }}^{2}$ & 0.4049 & 0.6193 & 0.6060 & 0.3036 & 0.3924 \\
\hline Adj R-squared & 0.3666 & 0.5616 & 0.5558 & 0.2673 & 0.3541 \\
\hline
\end{tabular}




\subsubsection{Impact of the Ownership Structure on the Cost of Capital}

The study of the relationship between the ownership structure and the cost of capital is done by the estimation of the pooled OLS regressions and the results are shown in the Table 13.

Table 13. Impact of the ownership structure on WACC.

\begin{tabular}{|c|c|c|c|c|c|}
\hline \multirow{2}{*}{ Variables } & \multicolumn{5}{|c|}{ WACC } \\
\hline & (1) & (2) & (3) & (4) & (5) \\
\hline INS & $\begin{array}{c}-0.0395^{* *} \\
(-2.21)\end{array}$ & $\begin{array}{c}-0.0053 \\
(-0.41)\end{array}$ & & & \\
\hline $\mathrm{IO}$ & $\begin{array}{c}-0.0776 \text { ** } \\
(-2.24)\end{array}$ & & $\begin{array}{c}-0.0922^{* * *} \\
(-2.83)\end{array}$ & & \\
\hline $\mathrm{BO}$ & $\begin{array}{c}0.0123 \\
(0.18)\end{array}$ & & & $\begin{array}{c}0.0218 \\
(0.32)\end{array}$ & \\
\hline $\mathrm{FO}$ & $\begin{array}{c}-0.0399 * * \\
(-2.18)\end{array}$ & & & & $\begin{array}{c}-0.0230 \\
(-1.78)\end{array}$ \\
\hline SIZE & $\begin{array}{c}-2.1311 * \\
(-1.93)\end{array}$ & $\begin{array}{c}-0.8702 \\
(-0.87)\end{array}$ & $\begin{array}{c}-1.0800 \\
(-1.12)\end{array}$ & $\begin{array}{c}-0.7497 \\
(-0.72)\end{array}$ & $\begin{array}{c}-1.3784 \\
(-1.34)\end{array}$ \\
\hline LEVERAGE & $\begin{array}{c}23.4654^{* * *} \\
(3.39)\end{array}$ & $\begin{array}{c}13.6195 * * * \\
(2.35)\end{array}$ & $\begin{array}{c}14.5367^{* * * *} \\
(2.66)\end{array}$ & $\begin{array}{c}12.5595^{* *} \\
(2.13)\end{array}$ & $\begin{array}{c}16.3156^{* * *} \\
(2.78)\end{array}$ \\
\hline ROA & $\begin{array}{c}-0.06336 \\
(-1.08)\end{array}$ & $\begin{array}{c}-0.0966 \\
(-1.58)\end{array}$ & $\begin{array}{c}-0.0755 \\
(-1.28)\end{array}$ & $\begin{array}{c}-0.0974 \\
(-1.59)\end{array}$ & $\begin{array}{c}-0.0863 \\
(-1.34)\end{array}$ \\
\hline $\mathrm{R}^{2}$ overall & 0.4655 & 0.3946 & 0.4462 & 0.4236 & 0.4034 \\
\hline Adj R-squared & 0.4337 & 0.3662 & 0.4201 & 0.3965 & 0.3754 \\
\hline
\end{tabular}

Table 13 shows the empirical results of the impact of the different ownership structure variables on the overall cost of capital. Regarding the objective of further investigating the separate impacts of the different ownership variables on the cost of capital, model (1) is re-estimated separately for the different ownership variables. The results reveal that in the baseline model (1), the institutional, the insider, and the foreign ownerships all have a negative and significant impact on the cost of capital. Meanwhile, the estimations of the models (2), (3), (4), and (5) show that only the insider ownership is negatively and significantly associated with the cost of capital. With regards to the control variables, only the leverage has a positive and significant relationship with the cost of capital. Furthermore, the same regressions have been re-estimated to separately determine the respective impacts of the different ownership structure variables on the cost of equity and the cost of debt. The empirical results reveal that the insiders and the foreign investors are efficient monitors in controlling the cost of equity (see Table A3) while only the insider ownership reduces the cost of debt (see Table A4). In all the regressions, the size has a negative and significant impact on the different costs. These results suggest that the parts held by the insiders and the foreign investors in the capital of the company as well as the large company's size are considered on the financial markets as positive signals about the financial stability and strength of the company and hence the stockholders and creditors would require lower returns on their long-term funds.

\subsubsection{Impact of the Non-Financial Disclosure and Ownership Structure on the Cost of Capital}

In this part of the empirical analysis, all the non-financial disclosures along with the different ownership structure variables have been estimated in one model. The empirical results are shown in the Table 14. 
Table 14. Impact of the non-financial disclosure and ownership structure on WACC.

\begin{tabular}{|c|c|c|}
\hline \multirow{2}{*}{ Variables } & \multicolumn{2}{|c|}{ Cost of Capital } \\
\hline & (1) & (2) \\
\hline ESG & $\begin{array}{c}-0.0060 * \\
(-1.80)\end{array}$ & \\
\hline ES & & $\begin{array}{c}0.0003 \\
(1.01)\end{array}$ \\
\hline SS & & $\begin{array}{c}0.0264 \\
(0.86)\end{array}$ \\
\hline GS & & $\begin{array}{c}-0.0716 \text { * } \\
(-1.86)\end{array}$ \\
\hline INS & $\begin{array}{c}-0.0128 * \\
(-1.85)\end{array}$ & $\begin{array}{c}-0.0018^{*} \\
(-1.67)\end{array}$ \\
\hline $\mathrm{IO}$ & $\begin{array}{c}-0.1134 \text { ** } \\
(-2.32)\end{array}$ & $\begin{array}{c}-0.0725 \text { * } \\
(-1.70)\end{array}$ \\
\hline $\mathrm{BO}$ & $\begin{array}{c}0.0351 \\
(0.71)\end{array}$ & $\begin{array}{c}-0.0763 \\
(-0.84)\end{array}$ \\
\hline $\mathrm{FO}$ & $\begin{array}{c}-0.0189 \\
(-1.44)\end{array}$ & $\begin{array}{c}-0.0108 \\
(-1.47)\end{array}$ \\
\hline SIZE & $\begin{array}{c}-1.1012 \\
(-1.27)\end{array}$ & $\begin{array}{c}-2.0684 \\
(-1.13)\end{array}$ \\
\hline LEVERAGE & $\begin{array}{c}11.2657^{* * *} \\
(5.28)\end{array}$ & $\begin{array}{c}6.4870 * * * \\
(2.64)\end{array}$ \\
\hline $\mathrm{ROA}$ & $\begin{array}{c}-0.0014^{* * *} \\
(-2.03)\end{array}$ & $\begin{array}{c}-0.1434^{* * *} \\
(2.70)\end{array}$ \\
\hline $\mathrm{R}^{2}$ overall & 0.4801 & 0.6583 \\
\hline Adj R-squared & 0.4376 & 0.5921 \\
\hline
\end{tabular}

Table 14 shows the empirical results of the impacts of the non-financial corporate disclosure and the different ownership structure variables on the overall cost of capital. Model (1) considers the ESG disclosure while model (2) separates between the environmental, social, and governance disclosures. The results reveal that in model (1), the ESG has a negative and significant impact on the cost of capital, which corroborates the results of the previous models. The findings of model (2) show that the governance disclosure is negatively and significantly associated with the cost of capital and that only the insider ownership is negatively and significantly associated to the cost of capital. In both models, the institutional and the insider ownerships as well as the ROA have negative impacts on the cost of capital while the leverage is positively and significantly associated with the cost of capital. The same regression has been re-estimated by considering as dependent variable the cost of equity and cost of debt, respectively. The empirical findings show that the ESG, the institutional, the insider, and the foreign ownerships have negative and significant relationships with the cost of equity while only the ESG, the institutional, and the insider ownerships have significant and negative impacts on the cost of debt. The leverage has always a positive and significant impact on both costs while the ROA affects always negatively and significantly the two types of costs (see Tables A5 and A6). These results indicate that the ESG disclosure, the institutional, and the insider ownerships along with low level of leverage and high level of ROA are relevant determinants in mitigating the cost of capital of the company. 


\section{Conclusions}

This study explores the impacts of the non-financial disclosure as well as the ownership structure on the cost of capital by using annual data of the listed companies on the UAE financial markets during the period 2010-2019. The results show a positive trend in the overall ESG disclosure (from $14.62 \%$ in 2010 to $26.86 \%$ in 2019 ) as well as in the environmental disclosure (from $10.41 \%$ in 2010 to $24.13 \%$ in 2019), social disclosure (from $22.19 \%$ to $27.09 \%$ in 2019 ), and governance disclosure (from $31.63 \%$ in 2010 to $41.23 \%$ in 2019) reflecting the increasing awareness about the importance of the ESG disclosure. This finding reflects the increasing awareness in the UAE about the importance of the non-financial disclosure as well the good implementation of the best ESG disclosure practices.

In addition, the empirical results reveal that the non-financial disclosure reduce the overall cost of capital as well the cost of equity and the cost of debt, separately. The compliance of the corporation with the best practices of the ESG disclosure and the consideration of the environmental, social, and governance dimensions in the annual reports indicate the assurance of the companies in improving their transparency, reducing the information asymmetry, as well as decreasing the cost of their capital. This result suggests that the stockholders and creditors are not only concerned about the financial reports, but also the non-financial information including the environmental, social, and corporate governance matters.

With regards to the ownership structure, the empirical results indicate that the presence of the insiders and the institutional investors in the capital of the company leads to the reduction in the cost of capital. This result suggests that the insider and the institutional owners are efficient monitors of the capital structure decisions and their presence contributes to the cost of capital minimization.

The above-mentioned findings would provide the companies traded on the UAE financial markets with an insight about the benefit of the ESG disclosure not only in terms of improving the transparency and compliance with the non-financial disclosure best practices, but also in terms of mitigating the cost of capital. This would help the financial regulators in the UAE in developing the ESG framework and disclosure guidelines to improve the transparency and reduce the information asymmetry on one side, and assist the companies in controlling more efficiently their capital structure decisions and reducing their costs of capital on the other.

This paper has limitations. First, although the data considered in the analysis include all the companies traded on the UAE financial markets that have an ESG score on Bloomberg, the sample remains small. Second, in this study, there was a consideration of the impact of only the ownership structure, as a measure of the corporate governance, on the cost of capital. Future researches can extend this study by considering other corporate governance mechanisms such as the board of directors along with its characteristics (size, duality, composition, and diversity) as well as the different corporate committees (audit, remuneration, nomination). Third, this research focused only on the UAE financial markets while this could be extended in further researches by considering the companies traded on the Gulf Cooperation Council (GCC) countries.

Funding: This research was not supported by any fund.

Conflicts of Interest: The author declares no conflict of interest. 


\section{Appendix A}

Table A1. Impact of the non-financial disclosure on the cost of equity.

\begin{tabular}{|c|c|c|c|c|c|}
\hline \multirow{2}{*}{ Variables } & \multicolumn{5}{|c|}{ Cost of Equity } \\
\hline & (1) & (2) & (3) & (4) & (5) \\
\hline ESG & $\begin{array}{c}-0.0119 \text { ** } \\
(-2.29)\end{array}$ & & & & \\
\hline ES & & $\begin{array}{c}-0.0334 \text { * } \\
(-1.67)\end{array}$ & $\begin{array}{c}-0.0426^{* *} \\
(-2.16)\end{array}$ & & \\
\hline SS & & $\begin{array}{c}-0.0047 \\
(-1.13) \\
\end{array}$ & & $\begin{array}{c}-0.0268 \\
(-1.01)\end{array}$ & \\
\hline GS & & $\begin{array}{c}-0.0327 \text { ** } \\
(-2.58)\end{array}$ & & & $\begin{array}{c}-0.0418 \text { ** } \\
(-1.27)\end{array}$ \\
\hline SIZE & $\begin{array}{c}-0.58015^{* *} \\
(-2.18)\end{array}$ & $\begin{array}{c}-0.69381 \\
(-1.38)\end{array}$ & $\begin{array}{c}-0.4372 \\
(-1.27)\end{array}$ & $\begin{array}{c}-1.254 * \\
(-1.88)\end{array}$ & $\begin{array}{c}-0.8563 \text { * } \\
(-1.71)\end{array}$ \\
\hline LEVERAGE & $\begin{array}{c}10.7040 \text { *** } \\
(4.90)\end{array}$ & $\begin{array}{c}21.2527^{* *} \\
(2.06)\end{array}$ & $\begin{array}{c}1.1123^{* *} \\
(2.26)\end{array}$ & $\begin{array}{c}3.8666^{*} \\
(1.72)\end{array}$ & $\begin{array}{c}3.4672 \text { ** } \\
(2.11)\end{array}$ \\
\hline ROA & $\begin{array}{c}-0.0305 \text { * } \\
(-1.67)\end{array}$ & $\begin{array}{c}-0.0970 \text { * } \\
(-1.61)\end{array}$ & $\begin{array}{c}-0.0984 \text { * } \\
(-1.73)\end{array}$ & $\begin{array}{c}-0.0076 \\
(-1.14) \\
\end{array}$ & $\begin{array}{c}0.0478^{*} \\
(1.77)\end{array}$ \\
\hline $\mathrm{R}^{2}$ overall & 0.4006 & 0.5996 & 0.5861 & 0.3642 & 0.4038 \\
\hline Adj R-squared & 0.3651 & 0.5389 & 0.5282 & 0.3206 & 0.3536 \\
\hline
\end{tabular}

* Significant at the level of $10 \%$; ** Significant at a level of $5 \%$; ${ }^{* *}$ Significant at a level of $1 \%$.

Table A2. Impact of the non-financial disclosure on the cost of debt.

\begin{tabular}{|c|c|c|c|c|c|}
\hline \multirow{2}{*}{ Variables } & \multicolumn{5}{|c|}{ Cost of Debt } \\
\hline & (1) & (2) & (3) & (4) & (5) \\
\hline ESG & $\begin{array}{c}-0.0062^{* *} \\
(-2.19)\end{array}$ & & & & \\
\hline ES & & $\begin{array}{c}-0.0020 * * \\
(-2.26)\end{array}$ & $\begin{array}{c}-0.0029^{* *} \\
(-2.51)\end{array}$ & & \\
\hline SS & & $\begin{array}{c}0.0076 \\
(-1.31) \\
\end{array}$ & & $\begin{array}{c}-0.0073 \text { * } \\
(-1.83)\end{array}$ & \\
\hline GS & & $\begin{array}{c}-0.0064^{* *} \\
(-1.99)\end{array}$ & & & $\begin{array}{c}-0.0032 \text { * } \\
(-1.69)\end{array}$ \\
\hline SIZE & $\begin{array}{c}-0.46319 \\
(-1.58)\end{array}$ & $\begin{array}{c}-0.0983 \\
(-1.34) \\
\end{array}$ & $\begin{array}{c}-0.1667 * \\
(-1.64)\end{array}$ & $\begin{array}{c}-0.4639 \text { ** } \\
(-1.92)\end{array}$ & $\begin{array}{c}-0.5005 \text { * } \\
(-1.73)\end{array}$ \\
\hline LEVERAGE & $\begin{array}{c}0.8308 \text { * } \\
(1.76)\end{array}$ & $\begin{array}{c}0.6654 \text { * } \\
(1.96)\end{array}$ & $\begin{array}{c}0.6663 * \\
(1.97)\end{array}$ & $\begin{array}{c}0.3087^{* *} \\
(1.91)\end{array}$ & $\begin{array}{c}0.8640 * \\
(1.83)\end{array}$ \\
\hline ROA & $\begin{array}{c}-0.0478 * \\
(-1.78)\end{array}$ & $\begin{array}{c}-0.0166 \text { * } \\
(-1.76)\end{array}$ & $\begin{array}{c}-0.0219 \text { ** } \\
(-2.43)\end{array}$ & $\begin{array}{c}-0.0147^{*} \\
(-1.74)\end{array}$ & $\begin{array}{c}-0.0024 \text { * } \\
(-1.69)\end{array}$ \\
\hline $\mathrm{R}^{2}$ overall & 0.4401 & 0.4932 & 0.4759 & 0.4240 & 0.3399 \\
\hline Adj R-squared & 0.3848 & 0.4164 & 0.4091 & 0.3783 & 0.2856 \\
\hline
\end{tabular}

* Significant at the level of $10 \%$; ** Significant at a level of $5 \%$. 
Table A3. Impact of the ownership structure on the cost of equity.

\begin{tabular}{|c|c|c|c|c|c|}
\hline \multirow{2}{*}{ Variables } & \multicolumn{5}{|c|}{ Cost of Equity } \\
\hline & (1) & (2) & (3) & (4) & (5) \\
\hline INS & $\begin{array}{c}-0.0146 \\
(-0.93)\end{array}$ & $\begin{array}{c}0.0142 \\
(0.98)\end{array}$ & & & \\
\hline $\mathrm{IO}$ & $\begin{array}{c}-0.2227 * * * \\
(-4.07)\end{array}$ & & $\begin{array}{c}-0.1515^{* * *} \\
(-4.00)\end{array}$ & & \\
\hline $\mathrm{BO}$ & $\begin{array}{c}0.1129^{* *} \\
(2.11)\end{array}$ & & & $\begin{array}{c}0.1134 \\
(-0.87)\end{array}$ & \\
\hline $\mathrm{FO}$ & $\begin{array}{c}-0.0425^{* * *} \\
(-2.95)\end{array}$ & & & & $\begin{array}{c}-0.1004^{* * *} \\
(-4.38)\end{array}$ \\
\hline SIZE & $\begin{array}{c}-2.4231^{* * *} \\
(2.79)\end{array}$ & $\begin{array}{c}-2.3217^{* *} \\
(2.50)\end{array}$ & $\begin{array}{c}-2.7583^{* * *} \\
(3.2)\end{array}$ & $\begin{array}{c}-0.3445 \\
(-0.17)\end{array}$ & $\begin{array}{c}-2.2070 \\
(-1.21)\end{array}$ \\
\hline LEVERAGE & $\begin{array}{c}3.4580 * \\
(1.83)\end{array}$ & $\begin{array}{c}2.1433 \\
(1.07)\end{array}$ & $\begin{array}{c}3.5604 \text { * } \\
(1.86)\end{array}$ & $\begin{array}{c}15.8833 \\
(1.41)\end{array}$ & $\begin{array}{c}27.1564^{* * * *} \\
\quad(2.62)\end{array}$ \\
\hline ROA & $\begin{array}{c}-0.0231 \\
(-0.47)\end{array}$ & $\begin{array}{c}-0.0206 \\
(-0.39)\end{array}$ & $\begin{array}{c}-0.0192 \\
(-0.39)\end{array}$ & $\begin{array}{c}-0.25147^{* *} \\
(-2.15)\end{array}$ & $\begin{array}{c}-0.2131 \text { ** } \\
(-1.99)\end{array}$ \\
\hline R-squared & 0.4708 & 0.3828 & 0.4365 & 0.3997 & 0.4036 \\
\hline Adj R-squared & 0.4372 & 0.3514 & 0.4077 & 0.3692 & 0.3732 \\
\hline
\end{tabular}

* Significant at the level of $10 \%$; ** Significant at a level of 5\%; *** Significant at a level of $1 \%$.

Table A4. Impact of the ownership structure on the cost of debt.

\begin{tabular}{|c|c|c|c|c|c|}
\hline \multirow{2}{*}{ Variables } & \multicolumn{5}{|c|}{ Cost of Debt } \\
\hline & (1) & (2) & (3) & (4) & (5) \\
\hline INS & $\begin{array}{l}0.0025 \\
(1.50)\end{array}$ & $\begin{array}{c}0.0027 \\
(1.09)\end{array}$ & & & \\
\hline $\mathrm{IO}$ & $\begin{array}{c}-0.0158^{* *} \\
(-1.98)\end{array}$ & & $\begin{array}{c}-0.0028 * \\
(-1.63)\end{array}$ & & \\
\hline $\mathrm{BO}$ & $\begin{array}{l}0.0076 \\
(1.00)\end{array}$ & & & $\begin{array}{c}0.0112 \\
(0.83)\end{array}$ & \\
\hline $\mathrm{FO}$ & $\begin{array}{c}0.0021 \\
(1.33)\end{array}$ & & & & $\begin{array}{c}-0.0086 \\
(-0.40)\end{array}$ \\
\hline SIZE & $\begin{array}{c}-0.2424^{* * *} \\
(-2.71)\end{array}$ & $\begin{array}{c}-0.3396^{* *} \\
(-2.14)\end{array}$ & $\begin{array}{c}-0.4049^{* * *} \\
(-2.63)\end{array}$ & $\begin{array}{c}-0.4085^{* * *} \\
(-2.67)\end{array}$ & $\begin{array}{c}-0.3696^{* *} \\
(-2.34)\end{array}$ \\
\hline LEVERAGE & $\begin{array}{c}0.0779 \\
(0.52)\end{array}$ & $\begin{array}{c}0.0552 \\
(0.56)\end{array}$ & $\begin{array}{c}0.2446 \\
(0.76)\end{array}$ & $\begin{array}{c}0.2343 \\
(0.73)\end{array}$ & $\begin{array}{c}0.1794 \\
(0.56)\end{array}$ \\
\hline ROA & $\begin{array}{c}-0.0040 \\
(-0.87)\end{array}$ & $\begin{array}{c}-0.0055 \\
(-0.66)\end{array}$ & $\begin{array}{c}-0.0076 \\
(-0.91)\end{array}$ & $\begin{array}{c}-0.0076 \\
(-0.73)\end{array}$ & $\begin{array}{c}-0.0055 \\
(-0.67)\end{array}$ \\
\hline R-squared & 0.2420 & 0.2376 & 0.2399 & 0.2407 & 0.2380 \\
\hline Adj R-squared & 0.1939 & 0.1989 & 0.2011 & 0.2020 & 0.1993 \\
\hline
\end{tabular}

${ }^{*}$ Significant at the level of $10 \%$; ${ }^{* *}$ Significant at a level of $5 \%$; ${ }^{* *}$ Significant at a level of $1 \%$. 
Table A5. Impact of the non-financial disclosure and ownership structure on the cost of equity.

\begin{tabular}{|c|c|c|}
\hline \multirow{2}{*}{ Variables } & \multicolumn{2}{|c|}{ Cost of Equity } \\
\hline & (1) & (2) \\
\hline ESG & $\begin{array}{c}-0.0335^{* *} \\
(-1.99)\end{array}$ & \\
\hline ES & & $\begin{array}{c}-0.0051 \\
(-1.08)\end{array}$ \\
\hline SS & & $\begin{array}{c}-0.0037 \\
(-1.08)\end{array}$ \\
\hline GS & & $\begin{array}{c}-0.1031 \text { * } \\
(-1.77)\end{array}$ \\
\hline INS & $\begin{array}{c}-0.0469 * * \\
(-2.14)\end{array}$ & $\begin{array}{c}-0.0039 \\
(-1.11)\end{array}$ \\
\hline $\mathrm{IO}$ & $\begin{array}{c}-0.1294 \text { * } \\
(-1.83)\end{array}$ & $\begin{array}{c}-0.5919 * * * \\
(-3.28)\end{array}$ \\
\hline $\mathrm{BO}$ & $\begin{array}{c}-0.0195 \\
(-1.27)\end{array}$ & $\begin{array}{c}-0.5215^{* * *} \\
(-5.28)\end{array}$ \\
\hline FO & $\begin{array}{c}-0.0734^{* * *} \\
(-3.85)\end{array}$ & $\begin{array}{c}-0.0299 * \\
(-1.87)\end{array}$ \\
\hline SIZE & $\begin{array}{c}-0.5502 \\
(-1.44)\end{array}$ & $\begin{array}{c}-3.1129 * * \\
(-2.12)\end{array}$ \\
\hline LEVERAGE & $\begin{array}{c}3.57803 * * \\
(1.97)\end{array}$ & $\begin{array}{c}11.3582 * \\
(1.90)\end{array}$ \\
\hline ROA & $\begin{array}{c}-0.0347 \\
(-1.51)\end{array}$ & $\begin{array}{c}-0.1360 * \\
(-1.69)\end{array}$ \\
\hline $\mathrm{R}_{\text {overall }}^{2}$ & 0.3022 & 0.4277 \\
\hline Adj R-squared & 0.2452 & 0.3169 \\
\hline
\end{tabular}

* Significant at the level of $10 \%$; ** Significant at a level of $5 \%$; *** Significant at a level of $1 \%$.

Table A6. Impact of the non-financial disclosure and ownership structure on the cost of debt.

\begin{tabular}{ccc}
\hline \multirow{2}{*}{ Variables } & \multicolumn{2}{c}{ Cost of Debt } \\
\cline { 2 - 3 } & $\mathbf{( 1 )}$ & $\mathbf{( 2 )}$ \\
\hline \multirow{2}{*}{ ESG } & $-0.0047^{*}$ & \\
& $(-1.88)$ & -0.0032 \\
\multirow{2}{*}{ ES } & & $(-1.34)$ \\
& & -0.0101 \\
SS & & $(-1.38)$ \\
\hline \multirow{2}{*}{ GS } & & $-0.0052 *$ \\
& & $(-1.82)$ \\
\hline \multirow{2}{*}{ INS } & $-0.0031^{* *}$ & -0.0026 \\
& $(-1.92)$ & $(-1.47)$ \\
\hline \multirow{2}{*}{ IO } & $-0.0197^{*}$ & $-0.0739 * * *$ \\
& $(-1.76)$ & $(-2.59)$ \\
\hline \multirow{2}{*}{ BO } & $0.0284^{* *}$ & $0.0614 * * *$ \\
& $(2.51)$ & $(2.82)$ \\
\hline \multirow{2}{*}{ FO } & 0.0042 & -0.0084 \\
& $(1.39)$ & $(1.55)$ \\
\hline & &
\end{tabular}


Table A6. Cont.

\begin{tabular}{|c|c|c|}
\hline \multirow{2}{*}{ Variables } & \multicolumn{2}{|c|}{ Cost of Debt } \\
\hline & (1) & (2) \\
\hline SIZE & $\begin{array}{c}-0.4897^{* *} \\
(-2.47)\end{array}$ & $\begin{array}{c}-0.0938 \\
(1.21)\end{array}$ \\
\hline LEVERAGE & $\begin{array}{c}0.7502 \text { ** } \\
(2.53)\end{array}$ & $\begin{array}{c}0.0900 \text { ** } \\
(2.10)\end{array}$ \\
\hline ROA & $\begin{array}{c}-0.0030 \text { * } \\
(1.82)\end{array}$ & $\begin{array}{c}-0.0160 \text { ** } \\
(-2.26)\end{array}$ \\
\hline $\mathrm{R}^{2}$ overall & 0.1775 & 0.2844 \\
\hline Adj R-squared & 0.1104 & 0.1459 \\
\hline
\end{tabular}

\section{References}

1. Sharfman, M.P.; Fernando, C.S. Environmental risk management and the cost of capital. Strateg. Manag. J. 2008, 29, 569-592. [CrossRef]

2. El Ghoul, S.; Guedhami, O.; Kwok, C.C.Y.; Mishra, D.R. Does corporate social responsibility affect the cost of capital? J. Bank. Financ. 2011, 35, 2388-2406. [CrossRef]

3. Dhaliwal, D.; Li, O.; Tsang, A.; Yang, G. Voluntary non-financial disclosure and the cost of equity capital: The initiation of corporate social responsibility reporting. Account. Rev. 2011, 86, 59-100. [CrossRef]

4. Dhaliwal, D.; Li, O.; Tsang, A.; Yang, G. Corporate social responsibility disclosure and the cost of equity capital: The roles of stakeholder orientation and financial transparency. J. Account. Public Policy 2014, 33, 328-355. [CrossRef]

5. Suto, M.; Takehara, H. CSR and cost of capital: Evidence from Japan. Soc. Responsib. J. 2017, 13, 798-816. [CrossRef]

6. Michaels, A.; Grüning, M. Relationship of corporate social responsibility disclosure on information asymmetry and the cost of capital. J. Manag. Control 2017, 28, 251-274. [CrossRef]

7. La Rosa, F.; Liberatore, G.; Mazzi, F.; Terzani, S. The impact of corporate social performance on the cost of debt and access to debt financing for listed European non-financial firms. Eur. Manag. J. 2018, 36, 519-529. [CrossRef]

8. Jensen, M.C.; Meckling, W.H. Theory of the firm: Managerial behavior, agency costs and ownership structure. J. Financ. Econ. 1976, 3, 305-360. [CrossRef]

9. Morck, R.; Shleifer, A.; Vishny, R.W. Management ownership and market valuation. J. Financ. Econ. 1988, 20, 293-315. [CrossRef]

10. Shleifer, A.; Vishny, R.W. A Survey of Corporate Governance. J. Financ. 1997, 52, 737-783. [CrossRef]

11. Short, H.; Keasey, K. Managerial ownership and the performance of firms: Evidence from the UK. J. Corp. Financ. 1999, 5, 79-101. [CrossRef]

12. Lin, C.; Ma, Y.; Malatesta, P.; Xuan, Y. Ownership structure and the cost of corporate borrowing. J. Financ. Econ. 2011, 100, 1-23. [CrossRef]

13. Shuto, A.; Kitagawa, N. The Effect of Managerial Ownership on the Cost of Debt. J. Account. Audit. Financ. 2011, 26, 590-620. [CrossRef]

14. Jahamani, Y.F. Green accounting in developing countries: The case of U.A.E. and Jordan. Manag. Financ. 2003, 29, 37-45. [CrossRef]

15. Nobanee, H.; Ellili, N.O. Corporate Sustainability Disclosure in Annual Reports: Evidence from UAE Banks: Islamic versus Conventional. Renew. Sustain. Energy Rev. 2016, 55, 1336-1341. [CrossRef]

16. Gerged, A.M.; Cowton, C.J.; Beddewela, E. Towards Sustainable Development in the Arab Middle East and North Africa Region: A Longitudinal Analysis of Environmental Disclosure in Corporate Annual Reports. Bus. Strat. Environ. 2017, 27, 572-587. [CrossRef]

17. Katsioloudes, M.; Brodtkorb, T. Corporate social responsibility: An exploratory study in the United Arab Emirates. SAM Adv. Manag. J. 2007, 72, 9-20. 
18. Kamla, R. Critically appreciating social accounting and reporting in the Arab Middle East: A postcolonial perspective. Adv. Int. Account. 2007, 20, 105-177. [CrossRef]

19. Rettab, B.; Ben Brik, A.; Kamel, M. A Study of Management Perceptions of the Impact of Corporate Social Responsibility on Business performance in Emerging Economies: The Case of Dubai. J. Bus. Ethics 2009, 89, 371-390. [CrossRef]

20. Khasharmeh, H.; Suwaidan, M.S. Social responsibility disclosure in corporate annual reports: Evidence from the Gulf Cooperation Council countries. Int. J. Account. Audit. Perform. Eval. 2010, 6, 327-345. [CrossRef]

21. Arshad, M.G.; Anees, F.; Ullah, M.R. The impact of corporate social responsibility on firm's financial performance. Int. J. Appl. Res. 2015, 4, 9-28.

22. Kolsi, M.C.; Attayah, O.F. Are socially responsible firms less engaged in earnings management? Evidence from ADX listed companies. Int. J. Bus. Innov. Res. 2018, 17, 536-560. [CrossRef]

23. Modigliani, F.; Miller, M.H. The Cost of Capital, Corporation Finance and the Theory of Investment. Am. Econ. Rev. 1958, 48, 261-297.

24. Modigliani, F.; Miller, M.H. Corporate Income Taxes and the Cost of Capital: A Correction. Am. Econ. Rev. 1963, 53, 433-443.

25. Jensen, M.C. Agency costs of free cash flow, corporate finance, and take-over. Am. Econ. Rev. 1986, 76, 323-329.

26. Myers, S.C.; Majluf, N.S. Corporate financing and investment decisions when firms have information that investors do not have. J. Financ. Econ. 1984, 13, 187-221. [CrossRef]

27. DeAngelo, H.; Masulis, R.W. Optimal capital structure under corporate and personal taxation. J. Financ. Econ. 1980, 8, 3-29. [CrossRef]

28. Myers, S.C. The Capital Structure Puzzle. J. Financ. 1984, 39, 575-592. [CrossRef]

29. Hussainey, K.; Al-Nodel, A. Corporate governance online reporting by Saudi listed companies. Res. Account. Emerg. Econ. 2008, 8, 39-64. [CrossRef]

30. Hassan, M.K. A disclosure index to measure the extent of corporate governance reporting by UAE listed corporations. J. Financ. Rep. Account. 2012, 10, 4-33. [CrossRef]

31. Nobanee, H.; Ellili, N.O.D. The impact of the mandatory corporate governance disclosures on the banking growth in UAE: Islamic versus conventional banks. Corp. Ownersh. Control. 2014, 12, 717-722. [CrossRef]

32. Rizk, R.; Dixon, R.; Woodhead, A. Corporate social and environmental reporting: A survey of disclosure practices in Egypt. Soc. Responsib. J. 2008, 4, 306-323. [CrossRef]

33. Nobanee, H.; Ellili, N. Impact of Economic, Environmental, and Social Sustainability Reporting on Financial Performance of UAE Banks. SSRN Electron. J. 2017. [CrossRef]

34. Naser, K.; Hassan, Y. Determinants of corporate social responsibility reporting: Evidence from an emerging economy. J. Contemp. Issues Bus. Res. 2013, 2, 56-74.

35. Alnaimi, H.A.; Hossain, M.; Momin, M.A. Corporate social responsibility reporting in Qatar: A descriptive analysis. Soc. Responsib. J. 2012, 8, 511-526. [CrossRef]

36. Abdu Rouf, M.D. The Corporate Social Responsibility Disclosure: A Study of Listed Companies in Bangladesh. Bus. Econ. Res. J. 2011, 2, 19-32.

37. Cormier, D.; Magnan, M. The impact of social responsibility disclosure and governance on financial analysts' information environment. Corp. Gov. Int. J. Bus. Soc. 2014, 14, 467-484. [CrossRef]

38. De Klerk, M.; De Villiers, C.; Van Staden, C. The influence of corporate social responsibility disclosure on share prices. Pac. Account. Rev. 2015, 27, 208-228. [CrossRef]

39. Muttakin, M.B.; Khan, A.; Azim, M.I. Corporate social responsibility disclosures and earnings quality. Manag. Audit. J. 2015, 30, 277-298. [CrossRef]

40. Haliwal, D.S.; Radhakrishnan, S.; Tsang, A.; Yang, Y.G. Nonfinancial Disclosure and Analyst Forecast Accuracy: International Evidence on Corporate Social Responsibility Disclosure. SSRN Electron. J. 2011, 87. [CrossRef]

41. Linsmeier, T.J.; Thornton, D.B.; Venkatachalam, M.; Welker, M. The Effect of Mandated Market Risk Disclosures on Trading Volume Sensitivity to Interest Rate, Exchange Rate, and Commodity Price Movements. Account. Rev. 2002, 77, 343-377. [CrossRef]

42. Uddin, M.H.; Hassan, M.K. Corporate Risk Information in Annual Reports and Stock Price Behavior in the United Arab Emirates. Acad. Account. Financ. Stud. J. 2011, 15, 59-84. 
43. Yang, S.-U. An Integrated Model for Organization-Public Relational Outcomes, Organizational Reputation, and Their Antecedents. J. Public Relations Res. 2007, 19, 91-121. [CrossRef]

44. Pound, J. Proxy contests and the efficiency of shareholder oversight. J. Financ. Econ. 1988, 20, $237-265$. [CrossRef]

45. Ortiz-Molina, H. Top Management Incentives and the Pricing of Corporate Public Debt. J. Financ. Quant. Anal. 2006, 41, 317-340. [CrossRef]

46. Jensen, M.C. The modern industrial revolution, exit, and the failure of internal control systems. J. Financ. 1993, 48, 831-880. [CrossRef]

47. Ellili, N. The Ownership Structure, The Board of Directors, and the Corporate Performance: Complementarity or Substitutability? Evidence from Companies Listed on Abu Dhabi Stock Exchange. Corp. Ownersh. Control 2012, 9, 276-287. [CrossRef]

48. Gaur, S.S.; Delios, A. International Diversification of Emerging Market Firms: The Role of Ownership Structure and Group Affiliation. Manag. Int. Rev. 2015, 55, 235-253. [CrossRef]

49. Bena, J.; Ferreira, M.A.; Matos, P.; Pires, P.M. Are foreign investors locusts? The long-term effects of foreign institutional ownership. J. Financ. Econ. 2017, 126, 122-146. [CrossRef]

(C) 2020 by the author. Licensee MDPI, Basel, Switzerland. This article is an open access article distributed under the terms and conditions of the Creative Commons Attribution (CC BY) license (http://creativecommons.org/licenses/by/4.0/). 